\title{
The Right to Non-intervention and Non-interference
}

\author{
Niki Aloupi*
}

\begin{abstract}
According to the common narrative, the right to non-intervention, concerning the state's territorial integrity, and the right to non-interference, concerning the matters which are not regulated by international law and in which the state has maintained its discretionary power, qualify together as one of the fundamental rights of states in the international legal order. This article examines the scope, meaning and legal implications of the non-intervention and non-interference principle and makes the argument that, despite its great importance as a rule of international law, its qualification as 'fundamental' adds nothing of substance to existing positive law. It is shown, on the one hand, that this right is not autonomous (as a liberty would be) since it is inevitably accompanied by a correlative duty of non-intervention and non-interference and, on the other, that the examined principle is entirely inherent in statehood. However, such inherence to statehood has no specific legal implications per se and does not establish an independent normative category which would allow one to distinguish between 'fundamental' rights or rights 'inherent to statehood' and the rest of states' 'ordinary' rights. Thus, in order to apprehend the normative status of the non-intervention/ non-interference principle in current international law, the only important question is whether it constitutes a jus cogens norm. The international law and practice examined show that only the core of the principle entailing the prohibition of an intervention or an interference with threat or use of illegal force is of a jus cogens order, whereas an intervention or interference without use of force does not violate jus cogens.
\end{abstract}

\section{Keywords}

Non-intervention, Non-interference, Rights of States, Fundamentality, Autonomy

\section{Introduction}

The so-called right to non-intervention and non-interference-notions being here used interchangeably-is often considered to constitute a classic manifestation of the doctrine of the fundamental rights of states. According to this common narrative, the right to non-intervention and non-interference qualifies as one of the fundamental rights of states in the international legal order. Yet, as is argued in this article, a closer look at the non-intervention and non-interference principle reveals numerous grey

\footnotetext{
* Professor, University of Strasbourg (France).
} 
areas concerning not only its exact scope and meaning, but, above all, its autonomous existence as a fundamental right.

It is submitted here that the autonomy of the right to non-intervention and noninterference is open to doubt for several reasons. In its first section, this paper argues that there seems to be no autonomy of such a right per se, and that in the current state of positive international law its qualification as 'fundamental', in Stephen C Neff's terms, as opposed to 'ordinary', 'add(s) nothing of substance to existing international law.' Nonetheless-as will be shown in the second section-the right to non-intervention and non-interference remains a well-established principle of international law, imposing not only duties upon all states, but also corresponding rights. The scope of the respective duties and rights of non-intervention and non-interference are gaining increasing importance in light of the fact that the legality of intervention and interference by certain states in the affairs of others will depend precisely on the definition and meaning of the principles examined in the present article. Subsequently, in the second section, the exact content of both norms within contemporary positive international law will be examined. In its final section, the article will offer insights on the right's normative authority, its legal implications, possible permissible derogations and exceptions and the consequences of its violation.

\section{The autonomous and fundamental nature of the right to non- intervention and non-interference}

The autonomy of the right to non-intervention and non-interference is open to challenge given its articulation along with other existing states' duties as well as states' constitutive elements and attributes. Two main challenges can be raised against this claim of autonomy, both of which shall be examined in the present section. By describing a given right as 'autonomous', what is meant is the degree to which it enjoys self-standing existence as a rule: does the principle constitute an independent rule that produces general legal effects irrespective of other rules of international law? Importantly, the autonomous character of a principle does not necessarily prejudge its fundamental character, as a right can be autonomous while still being fundamental in nature.

2.1 First challenge to the autonomy of the right: Correlative duties and absence of a clearly identified liberty

First of all, the right to non-intervention and non-interference is 'merely the counterpart of some other state's duty, ${ }^{2}$ as is illustrated by the United Nations General Assembly's

1 Stephen C Neff, 'The Dormancy, Rise and Decline of Fundamental Liberties of States' (2015) 4 CJICL 482, 497.

2 ibid 483. 
Declaration on the Inadmissibility of Intervention and Interference in the Internal Affairs of States. ${ }^{3}$ This is of course, strictly speaking, the case for all rights: they are never entirely autonomous given their correlative international obligations. Only a state's liberty, in Hohfeld's terminology, ${ }^{4}$ can be considered as being a truly autonomous rule producing legal effects independently from any other rule of international law. Certainly, if a state's internal affairs are defined as the sum of the matters regarding which a state is free to exercise its own unilateral will in a discretionary manner without outside interference, it would seem prima facie that non-interference constitutes a liberty (as opposed to a right). However, this is a false assumption. Indeed, such a liberty would exist only if it were possible to materially define and determine a 'reserved domain', that is, if there were a list of the matters that are by nature within the domestic jurisdiction of states. ${ }^{5}$ As will be demonstrated below, and as has been affirmed by Neff, ${ }^{6}$ such a list does not exist. As discussed further below, any matter, internal or international, subject to the state's exclusive or concurrent jurisdiction can be subtracted from the residual liberty of a state that assumes an international engagement regarding it. The European Union is a topical illustration of this point: within the Union, sovereign states have transferred numerous powers and competencies to a sui generis international organisation, including some that are traditionally considered as domestic matters-most notably the economic domain.

The point that the right to non-interference is neither autonomous nor a liberty as such is evident from the negative formulation of the right. Consequently, the fact remains that the right to non-interference does not have autonomous content independent from the correlative prohibition, and is not materially defined in a positive manner as a liberty. Non-intervention/non-interference is a right and not a liberty and, as such, it constitutes merely the 'flip side' of other states' correlative duties. Therefore, it seems that the formulation 'right to non-interference', instead of 'duty of non-interference' or 'principle of non-interference', has perhaps a purely semantic or symbolic value and does not establish a distinctive legal category with legal implications other than those already existing in contemporary positive international law.

\subsection{Second challenge to the autonomy of the right: Derivation from statehood}

It is submitted here that the right to non-intervention and non-interference is inherent in statehood ${ }^{7}$ - perhaps even within the logic of the international legal order ${ }^{8}$-and thus that its autonomy as an independent fundamental right is difficult to appreciate. Indeed, it

3 UNGA Res 36/103 (9 December 1981) UN Doc A/RES/36103.

4 Wesley Newcomb Hohfeld, Fundamental Legal Conceptions as Applied in Judicial Reasoning and other Legal Essays (Yale UP 1923) 38-50; Neff (n 1) 483-84.

5 Neff (n 1) 497.

6 ibid.

7 On rights inherent to statehood, see generally Jean d'Aspremont, 'The Doctrine of Fundamental Rights of States and Anthropomorphic Thinking in International Law' (2015) 4 CJICL 501.

8 See generally Raymon John Vincent, Nonintervention and International Order (Princeton UP 1974). 
can be considered to be the 'mere legal illustration' of the factual elements that constitute the conditions for the existence of any state. ${ }^{9}$ Non-intervention is the legal guarantee of the state's territory-its integrity, inviolability and subjection to the exclusive jurisdiction of the state-whereas non-interference is inferred from political independence, both internal and external. ${ }^{10}$ Thus, non-intervention and non-interference are implied by two of the state's constitutive elements, and are correlatives to its essential attribute, sovereignty, which in turn is logically inferred from statehood as its necessary legal implication. ${ }^{11}$ Article 2(1) of the Charter of the United Nations (UN Charter), ${ }^{12}$ which establishes the principle of sovereign equality between its members, is often considered as closely related to the non-intervention/non-interference principle. Sovereignty entails independence and obliges third states to respect the exclusive jurisdiction a state exercises on its own territory as well as its political autonomy. In a way, the principle of noninterference is the juridical mirror image of the factual existence and legal sovereignty of states. ${ }^{13}$

\subsection{Challenging its qualification as a 'fundamental' right}

One must also wonder whether the qualification of the right of non-intervention/noninterference as fundamental would be of any use to existing international law. ${ }^{14}$ As was argued in the previous section, the right to non-intervention and non-interference clearly lacks autonomy. It is hard to see how asserting the status of the right as fundamental could give it any superior normative authority which is not based on the system of positive sources of international law without resorting to naturalistic considerations. Ricardo J Alfaro suggests that the fundamental character of certain rights may be due to the fact that these rights are not created by states, but simply exist because of their inherence and close relation to statehood, and are therefore 'a direct emanation of the State itself'. ${ }^{\text {' }}$

9 Florence Poirat, 'La Doctrine des “Droits Fondamentaux” de l'État' (1992) 16 Droits: Revue Française de Théorie Juridique 83, 89.

10 ibid; Robert Jennings and Arthur Watts (eds), Oppenheim's International Law, vol 1 (9th edn, OUP 2008) 428; Ricardo J Alfaro, 'The Rights and Duties of States' (1959) 97 RCADI 91, 112. For the distinction between non-intervention stricto sensu and non-interference lato sensu, see below section 2.1.

11 Poirat (n 9) 89. See also Henry Bonfils, Manuel de Droit International Public (3rd edn, Rousseau 1901) paras 237, 126: without fundamental rights 'l'État n'existerait pas comme entité politique indépendante'.

12 Charter of the United Nations (adopted 26 June 1945, entered into force 24 October 1945) 1 UNTS XVI (UN Charter).

13 Poirat (n 9) 89. See also the reasoning of the Constitutional Court of Ukraine in On Conducting AllCrimean Referendum, Decision No 2-rp/2014 (14 March 2014); On the Declaration of Independence of the Autonomous Republic of Crimea and the City of Sevastopol, Decision No 3-rp/2014 (20 March 2014). Territorial integrity and inviolability are considered by the Court to be the necessary and logical corollaries of state sovereignty.

14 For a discussion of what the fundamental rights of states are, see Daniel H Joyner and Marco Roscini, 'Is There Any Room for the Doctrine of Fundamental Rights of States in Today's International Law?' (2015) 4 CJICL 467.

15 Alfaro (n 10) 109. 
Such inherence in statehood, however, has no specific legal implications and cannot per se establish an independent normative category, which would allow distinction between rights fundamental or inherent in statehood on the one hand, and the 'ordinary' rights of states on the other. In other words, an unlawful intervention or interference is first and foremost a violation of a state's sovereignty, but has no legal specificity as such.

Even if one links the fundamental character of the right in question to jus cogens, it would be difficult to conclude sic et simpliciter that the right to non-interference and non-intervention is a fundamental one. Indeed, violations of this right constitute a violation of a peremptory norm of general international law only when, and to the extent that, such a violation of a state's sovereignty constitutes an unlawful use of armed force. Jus cogens, therefore, will not be deemed to have been violated every time that the non-intervention/non-interference principle is itself violated. Furthermore, as it will be shown in section three, attenuations of, or derogations from, the non-intervention/noninterference prohibition indeed exist and are quite numerous.

Any fundamentality of the right to non-intervention and non-interference, then, would derive from the respect due to the state's constitutive elements, but neither from its particular nature as a special category of rights nor from the concept of jus cogens as such. The qualification of this right as a fundamental one would thus have no added value for positive international law and could only lead to erroneous assumptions or confusions. Hence there is no need to refer to an independent fundamental right to nonintervention and non-interference. There is, however, great need for identification and definition of the principle's scope and meaning.

\section{Meaning and legal regime of the right to non-intervention and non- interference}

Even though the customary status of the principle of non-intervention/non-interference seems uncontroversial, ${ }^{16}$ its exact content is far from obvious. Indeed, although this principle appears in several international instruments ${ }^{17}$ and the case law of the

16 Case Concerning Military and Paramilitary Activities in and against Nicaragua (Nicaragua $v$ United States of America) (Merits) [1986] ICJ Rep 14, 106 (Nicaragua): 'The principle of non-intervention involves the right of every sovereign State to conduct its affairs without outside interference; though examples of trespass against this principle are not infrequent, the Court considers that it is part and parcel of customary international law.'

17 Amongst others: Montevideo Convention on the Rights and Duties of States (adopted 26 December 1933, entered into force 26 December 1934) 165 LNTS 19, art 8 ('No state has the right to intervene in the internal or external affairs of another'); Declaration on Principles of International Law Concerning Friendly Relations and Co-operation Among States in Accordance with the Charter of the United Nations, UNGA Res 2625 (XXV) (24 October 1970) UN Doc A/RES/25/2625 (Friendly Relations Declaration), art 1 (concerning the third principle, 'The principle concerning the duty not to intervene in matters within the domestic jurisdiction of any State, in accordance with the Charter', and stating that '[n]o State or group of States has the right to intervene, directly or indirectly, for any reason whatever, in the internal or external affairs of any other State. Consequently, armed intervention and all other forms of interference 
International Court of Justice (ICJ), ${ }^{18}$ it remains unclear what is included in this right or, inversely, what is covered by such a prohibition. If the core of the principle can be considered certain, its limits and precise extent are very much open to debate.

As enshrined in various international instruments and customary international law, the non-intervention/non-interference principle seems to include at least two different categories of rights and duties, each revealing a different side of the principle, and each being implied by a different attribute of sovereign states. This dichotomy is clear in the United Nations General Assembly's Declaration on the Inadmissibility of Intervention and Interference in the Internal Affairs of States. ${ }^{19}$ Indeed, after stating in article 1 that '[n]o State or group of States has the right to intervene or interfere in any form or for any reason whatsoever in the internal and external affairs of other States', the Declaration provides in article 2 a long list of rights and corresponding duties of states comprising the non-intervention/non-interference principle, before affirming in article 3 that ' $t$ ] he right and duties set out in this Declaration are interrelated and are in accordance with the Charter of the United Nations'.

In fact, notwithstanding the scholarly debate about the exact contours of the principle, two main-similar but not identical-aspects of non-intervention/non-interference can be identified. Even though both of these elements appear to be directly implied by the principle of equal sovereignty, they derive from different principles of international law. Each corresponds to a different constitutive (factual) element of the state. The first facet

or attempted threats against the personality of the State or against its political, economic and cultural elements, are in violation of international law'); Constitutive Act of the African Union (adopted 11 July 2000, entered into force 26 May 2001) OAU Doc CAB/LEG/23.15, art 4(g) (setting out the principle of 'non-interference by any Member State in the internal affairs of another'); Final Communiqué of the Asian-African Conference of Bandung (24 April 1955) pt G ('Declaration on the Promotion of World Peace and Co-operation') principle 4 ('Abstention from intervention or interference in the internal affairs of another country'); International Law Commission (ILC), 'Draft Declaration on Rights and Duties of States' (1949) ILC YB 287, art 1; Charter of the Organization of American States (adopted 30 April 1948, entered into force 13 December 1951) 119 UNTS 3, arts 3(e) ('Every State has the right to choose, without external interference, its political, economic, and social system and to organize itself in the way best suited to it, and has the duty to abstain from intervening in the affairs of another State. Subject to the foregoing, the American States shall cooperate fully among themselves, independently of the nature of their political, economic, and social systems'), 13, 15, 17, 19 ('No State or group of States has the right to intervene, directly or indirectly, for any reason whatever, in the internal or external affairs of any other State. The foregoing principle prohibits not only armed force but also any other form of interference or attempted threat against the personality of the State or against its political, economic, and cultural elements').

18 See primarily Corfu Channel Case (United Kingdom v Albania) (Merits) [1949] ICJ Rep 4, 35; Nicaragua (n 16) 106-08 ('[The Court] has to consider whether there might be indications of a practice illustrative of belief in a kind of general right for States to intervene, directly or indirectly, with or without armed force, in support of an internal opposition in another State, whose cause appeared particularly worthy by reason of the political and moral values with which it was identified. For such a general right to come into existence would involve a fundamental modification of the customary law principle of non-intervention'); Case Concerning Armed Activities on the Territory of the Congo (Democratic Republic of the Congo $v$ Uganda) (Merits) [2005] ICJ Rep 168, 227.

19 UNGA Res 36/103 (9 December 1981) UN Doc A/RES/36103, recalling in its preamble the Declaration on the Inadmissibility of Intervention in the Domestic Affairs of States and the Protection of their Independence and Sovereignty, UNGA Res 2131 (XX) (21 December 1965) UN Doc A/RES/20/2131. 
of non-intervention/non-interference derives from the principle of territorial integrity and inviolability and prohibits certain actions on foreign soil, whereas its second facet derives from the principle of a state's independence and prohibits any interference in a state's domestic affairs.

Such a distinction between non-intervention (territorial integrity) and noninterference (independence and autonomy) seems theoretically clear. Nevertheless, the lines are blurred by the fact that a third principle is closely interrelated with the previous two, making the contours of each right and correlative duty difficult to establish. The customary prohibition of any threat or use of force against the territorial integrity or political independence of any state, as codified in article 2(4) of the UN Charter, is often intrinsically linked to the non-intervention/non-interference principle. This association raises the question whether, and to what extent, acts constituting interference without the use of force can be covered by the non-intervention/non-interference principle.

\subsection{Non-intervention against the territorial inviolability and integrity of a state}

The principle of territorial inviolability and integrity primarily entails that all intervention-meaning here any material, physical action by a third state-on foreign soil, without the territorial state's consent, is illegal under international law. ${ }^{20}$ The nonintervention principle thus comprises, first of all, the right of any state and the correlative duty of all other states to respect the exclusivity of the territorial state's jurisdiction and its exclusive right to exercise operational powers on its territory. ${ }^{21}$ United Nations General Assembly Resolution 3171 of 17 December 1973 expressly links the non-intervention principle to the principle of territorial integrity. ${ }^{22}$ In this regard, being beyond any doubt that all action on foreign soil comporting unlawful use of force constitutes a prohibited intervention, ${ }^{23}$ it is also certain that even other actions not including the use of force by a third state's authorities on foreign soil can be covered by the territorial integrity principle and by the non-intervention prohibition. ${ }^{24}$ Indeed, United Nations practice and ICJ jurisprudence have shown that it is not only the direct occupation of a state's territory

20 Unless of course there is an authorisation by the Security Council or the state acts in self-defence, as it will be argued further in this article.

21 Jean Combacau and Serge Sur, Droit International Public (10th edn, Monchrestien 2012) 264.

22 UNGA Res 3171 (XXVII) (17 December 1973) UN Doc A/RES/3171, para 6: 'Emphasizes the duty of all States to refrain in their international relations from military, political, economic or any other form of coercion aimed against the territorial integrity of any State and the exercise of its national jurisdiction' (emphasis in original).

23 Lawful use of force in conformity with general international law and the UN Charter would of course not constitute a prohibited intervention: $\mathrm{cf}$ n 19.

24 Case of the SS 'Lotus' (France v Turkey) (Judgment) PCIJ Rep Series A No 10, 18-19: 'Now the first and foremost restriction imposed by international law upon a State is that-failing the existence of a permissive rule to the contrary-it may not exercise its power in any form in the territory of another State. In this sense jurisdiction is certainly territorial; it cannot be exercised by a State outside its territory except by virtue of a permissive rule derived from international custom or from a convention.' See also Corfu Channel Case (n 18) 35. 
that constitutes a violation of its territorial integrity, but also indirect involvement by other states in its internal affairs, such as the provision of material aid to rebels to gain control of a part of its territory. ${ }^{25}$ However, the latter is closely connected to the second aspect of the non-intervention/non-interference principle.

\subsection{Non-interference against the independence and autonomy of a state}

Another facet of non-intervention/non-interference is that it 'forbids all States or groups of States to intervene directly or indirectly in internal or external affairs of other States. ${ }^{26}$ These 'affairs' are defined-in a tautological manner-as all 'matters in which each State is permitted, by the principle of State sovereignty, to decide freely' ${ }^{27}$ The non-interference right derives this time from state independence (the corollary of external sovereignty) and autonomy (the corollary of internal sovereignty). Thirdparty states should in fact not interfere with whatever matter falls within the 'sphere of residual liberty ${ }^{28}$ of a sovereign state. As such, this principle, which the ICJ recognised as customary in nature in the Nicaragua case, is reaffirmed inter alia in the 1970 Friendly Relations Declaration, ${ }^{29}$ as far as inter-state relations are concerned, and in article 2(7) of the UN Charter, as far as relations between states and the UN are concerned. ${ }^{30}$ Even though there is no doubt as to the existence of such a principle of non-interference, it remains to be seen what is covered by it. In this regard, one must first examine which are the matters 'in which each state is permitted to decide freely' or, in other words, according to the UN Charter, 'which are essentially within the domestic jurisdiction of any state. ${ }^{31}$

As regards this inquiry, there is a common doctrinal confusion ${ }^{32}$ between different terms and notions revolving around the same concept: domaine réservé or 'reserved domain', 'private life, ${ }^{33}$ 'internal affairs', 'matters within the domestic jurisdiction of any

25 Nicaragua (n 16) 124-25.

26 ibid 108.

27 ibid.

28 Jean Combacau, 'Pas une Puissance, une Liberté: La Souveraineté Internationale de l'État' (1993) 67 Pouvoirs 47, 53, 57-8 (translated by author).

29 Friendly Relations Declaration, art 1, principles 3, 5(1).

30 According to article 2(7) of the UN Charter, 'Nothing contained in the present Charter shall authorize the United Nations to intervene in matters which are essentially within the domestic jurisdiction of any state or shall require the Members to submit such matters to settlement under the present Charter; but this principle shall not prejudice the application of enforcement measures under Chapter VII.'

31 UN Charter, art 2(7).

32 cf Lino Di Qual, La compétence liée (LGDJ 1964) 581-91; Charles Rousseau, 'L'indépendance de l'État dans l'ordre international' (1948) 73 RCADI 167, 234-49; Charles Rousseau, 'L'Aménagement des Compétences en Droit International Public' (1930) 37 RGDIP 420, 446-59; Georges Scelle, Précis de Droit des Gens: Principes et Systématique (Bibliothèque Dalloz 2008) 90-94; Georges Scelle, 'Règles Générales du Droit de la Paix' (1933) 46 RCADI 327, 365-94.

33 Joe Verhoeven, 'Non-intervention: “Affaires Intérieures" ou "Vie Privée"?' in Le Droit International au Service de la Paix, de la Justice et du Développement: Mélanges Michel Virally (Pedone 1991) 493. 
State' or even 'jurisdiction which, in principle, belongs solely to the State (...) [being] exclusive jurisdiction. ${ }^{34}$ In this regard, it must be emphasised that, contrary to what was asserted up until the nineteenth century, there are no matters that are domestic by nature. ${ }^{35}$ Consequently, there is no pre-determined list of what rests within the domestic jurisdiction of a state. ${ }^{36}$ Indeed, the 'reserved domain' of a state consists of all matters for which this state has not yet undertaken any international commitment and thus it remains free not only to exercise (or not) its unilateral will, but also to determine the way in which it will exercise it. Therefore, it is not the exclusivity of the state's jurisdiction that determines the matters covered by the principle of non-interference. What matters most, in fact, is the discretionary nature of its powers and jurisdiction. ${ }^{37}$ In fact, the matters on which a state can exercise its discretionary powers are those not limited in any way ${ }^{38}$ by customary or conventional international law. ${ }^{39}$ It is precisely these matters that are covered by the non-interference principle. Thus, they are by definition relative and contingent depending on the choices that each state makes at any given time as regards its international engagements. These international engagements can even be taken on concerning what is usually considered, in the words of article 2(7) of the UN Charter, to fall within 'matters of (...) domestic jurisdiction', namely the 'political, economic, social and cultural system, and the formulation of foreign policy', 40 since there are no 'domestic matters' by nature as already mentioned.

The sole limitation-though it is an unclear and ambiguous one-to this relativity as to what constitutes a state's reserved domain would be the extent to which the state can limit its discretionary powers and initial residual liberty without giving up the very essence of what makes it a state. ${ }^{41}$ Or, put it another way, can a state maintain its status as sovereign if it renounces part of its prerogative powers? The question is largely theoretical, but it does not lack interest. The answer might allow for the identification of

34 Nationality Decrees Issued in Tunis and Morocco (Advisory Opinion) PCIJ Rep Series B No 4, 24.

35 See Verhoeven, 'Non-intervention' (n 33) 499 ('Ce n'est pas qu'il y ait quelque sphère "privée”, c'est-à-dire des affaires “intérieures”, qui serait soustraite au droit des gens'); Combacau (n 28) 53 (le domaine réservé ne l'est pas 'par nature, mais parce que l'État visé l'inclut encore dans l'enceinte de sa liberté résiduelle'). See also Accordance with International Law of the Unilateral Declaration of Independence in Respect of Kosovo (Advisory Opinion) [2010] ICJ Rep 403, 440 ('At the same time, the Court observes that the Constitutional Framework functions as part of a specific legal order, created pursuant to resolution 1244 (1999), which is applicable only in Kosovo and the purpose of which is to regulate, during the interim phase established by resolution 1244 (1999), matters which would ordinarily be the subject of internal, rather than international, law') (emphasis added).

36 cf Neff (n 1) 482.

37 Combacau and Sur (n 21) 265.

38 There is a sole potential (and uncertain) exception regarding the international prohibition on abuse of rights.

39 See Institute of International Law (IDI) Aix-en-Provence Resolution, 'La Détermination du Domaine Réservé et ses Effets' (1954) 45 Annuaire IDI 292, art 1 ('Le domaine réservé est celui des activités étatiques où la compétence de l'État n’est pas liée par le droit international').

40 Nicaragua (n 16) 108.

41 See Combacau (n 28) 57-8; Poirat (n 9) 90-91; Helmut Philipp Aust, 'Fundamental Rights of States: Constitutional Law in Disguise?' (2015) 4 CJICL 521. 
a core of matters that must remain within the discretionary powers and competence of the state for it to go on being considered as one. However, it must be noted that such a potential list of matters would not be one of matters domestic by nature as for example the (very short) list of the legal implications of the factual constitutive elements that allow a state to come into existence. ${ }^{42}$ In any case, it should be borne in mind that it is an attribute of the sovereign state to decide the termination of its own existence. If it renounces one or more of its constitutive elements, it does not commit an internationally wrongful act, nor does it violate any jus cogens norm. In one author's words, 'Because it is sovereign, a state has a right to commit suicide! ${ }^{43}$

Whatever the answer to this last, largely theoretical and hypothetical, question may be, it is now clear that two separate aspects of the non-intervention/non-interference principle have been identified, namely non-intervention concerning territorial integrity, and non-interference concerning matters which are not regulated by international law and in which the state maintains its discretionary power. If these definitions are accepted, non-interference can be considered a wider notion than non-intervention, the latter's scope being limited solely to the exclusivity of a state's territorial jurisdiction. ${ }^{44}$ Consequently, intervention can be seen as a form or modality of interference, but intervention does not exhaust the scope of interference. There is thus no automatic and integral assimilation between the two, even though they mostly overlap. They can be analysed as either constituting two separate but concomitant rights or, more precisely and preferably, as one right to non-interference lato sensu which includes-in its corethe right to non-intervention stricto sensu, and is thus referred to in this article as the non-intervention/non-interference principle.

If the meaning of non-intervention/non-interference is thus identified, its legal regime-notably the conditions under which an intervention or interference would be prohibited as illegal or unlawful under international law-remains unclear. Indeed, all intervention-and a fortiori all interference-does not necessarily violate international law, not only because of the exceptions to the principle, which will be examined under section three, but also because some conditions have to be met in order for an interference to be unlawful. Indeed, the illegality of the interference is undoubtable when it constitutes a use of force not allowed by international law, since in such a case the acts constituting an intervention/interference are simultaneously prohibited by article 2(4) of the UN Charter. However, it is far more delicate to determine to what extent acts not involving unlawful or unauthorised use of force can be characterised as an illegal intervention or interference. In this regard, the exact content of the principle is still open to important doubts, which are further reinforced by recent state practice, as will be argued in section three.

42 See infra.

43 Poirat (n 9) 91 (translated by author).

44 cf Raphaële Rivier, Droit International Public (2nd edn, Themis 2014) 258. 


\subsection{Non-intervention/non-interference and the use of force}

The principle of non-intervention has always been closely linked to article 2(4) of the UN Charter, dealing with the prohibition of the threat or use of force. Unlawful threat or use of force against the territorial integrity or political independence of any state violates simultaneously both the prohibition of use of force and the proscription on illegal intervention. However, does this mean, a contrario, that interference with no threat or use of force is not illegal under international law? According to the ICJ in the Nicaragua case:

Intervention is wrongful when it uses methods of coercion in regard to such choices, which must remain free ones. The element of coercion, which defines, and indeed forms the very essence of, prohibited intervention, is particularly obvious in the case of an intervention which uses force, either in the direct form of military action, or in the indirect form of support for subversive or terrorist armed activities within another State. ${ }^{45}$

We can deduce from this statement that intervention or interference can be illegal under international law even when there is no unlawful use of force implicated, ${ }^{46}$ provided that the element of coercion is present. According to Oppenheim's International Law, 'intervention is forcible or dictatorial interference by a state in the affairs of another state, calculated to impose certain conduct or consequences on that other state', and the principle of non-interference prohibits interference that is 'forcible or dictatorial, or otherwise coercive, in effect depriving the state intervened against of control over the matter in question. 47

It is of course obvious that there is always coercion when there is the use of force. Nevertheless, it is far more complex to determine whether there would be coercion in the absence of a threat or use of force. It would seem for instance that simple verbal declarations or recognitions, even commenting on matters that fall within a third state's 'reserved domain', for example encouraging a secession or condemning a state's internal politics, would not automatically constitute an illegal interference, since the element of coercion may be considered absent or insufficient. ${ }^{48}$ However, unlawful interference can still be triggered even by verbal declarations aiming at influencing a third state by putting it under pressure or by other non-material and non-forcible actions. This appears to be the case particularly in two extreme hypotheses. ${ }^{49}$

First, whenever the actions or declarations in question aim at intentionally affecting the stability of a government. Such actions, even non-material, could be considered as coercive per se and thus illegal. Therefore, encouraging a secession with the intention

45 Nicaragua (n 16) 108 (emphasis added).

46 As the ICJ stated the Nicaragua case, the principle of non-intervention prohibits a state 'to intervene, directly or indirectly, with or without armed force, in support of an internal opposition in another State': ibid 108 (emphasis added).

47 Jennings and Watts (n 10) 430, 432.

48 See Olivier Corten, 'Déclarations Unilatérales d'Indépendance et Reconnaissances Prématurées: Du Kosovo à l'Ossétie du Sud et à l'Abkhazie' (2008) 112 RGDIP 721.

49 On these two hypotheses, see Combacau and Sur (n 21) 266. 
to destabilise the existing government, even in a solely verbal way with no concrete action undertaken other than declarations, might qualify as an illegal interference. It has even been argued that mere premature recognition of a declaration of independence following a secession would constitute a coercive and thus unlawful interference. ${ }^{50}$ Nonetheless, such a prohibition does not seem to be accepted in the current state of positive international law, recognition remaining a discretionary power of all states, only partially and lightly limited by the so-called 'obligation of non-recognition.' ${ }^{\text {'1 }}$

Second, whenever the immaterial non-forcible actions in question result in depriving a state of a legal right to which it was entitled. However, in that case the illegal interference consists simultaneously of the violation of a previous international obligation by the interfering state and thus has no autonomy.

That being said, there is still great uncertainty regarding the element of coercion and its definition as regards illegal interference. It is indeed extremely difficult to draw a clear line between what constitutes internationally lawful political or economic ${ }^{52}$ pressure against a third state, and what is qualified as coercion and thus as unlawful interference. In any case, the relationship between the prohibition on the threat or use of force and principle of non-intervention/non-interference reveals once again-and from yet another point of view-the limits of an autonomous right to non-intervention and non-interference. It is indeed obvious that, when the illegality of an intervention or interference consists of the threat or use of force against the territorial integrity or the political independence of a state, there is no autonomy of the non-intervention/ non-interference prohibition and no need to consider that a fundamental right has been violated as such. Still, the legal consequences of such a violation, as well as the exceptions to such a prohibition, need to be addressed.

\section{Exceptions to and sanction of prohibition of non-intervention and non-interference}

The derogability of the non-intervention/non-interference prohibition and the consequences of its violation are dependent on its normative authority-that is, on whether

50 See Joe Verhoeven, 'La Reconnaissance Internationale: Déclin ou Renouveau?' (1993) 39 AFDI 7, 21. See also arguments made by Serbia, 'Letter dated 6 March 2008 from the Chargé d'Affaires ai of the Permanent Mission of Serbia to the United Nations Addressed to the President of the Security Council' (6 March 2008) UN Doc S/2008/162 (concerning the recognition of Kosovo's declaration of independence); and by Georgia, UNSC Verbatim Record (28 August 2008) UN Doc S/PV.5969 (on the recognition of Abkhazia's and South Ossetia's independence). For a different perspective on this matter, see Corten, 'Déclarations Unilatérales d'Indépendance et Reconnaissances Prématurées' (n 48). Arguing that premature recognition is an unlawful interference, see John Dugard and David Raič, 'The Role of Recognition in the Law and Practice of Secession' in Marcelo G Kohen (ed), Secession: International Law Perspectives (CUP 2006); cf Eric David, 'Portée et Limite du Principe de Non-Intervention' (1990) 2 RBDI 351.

51 See infra, in section three.

52 See Antonios Tzanakopoulos, 'The Right to be Free from Economic Coercion' (2015) 4 CJICL 616. 
it has achieved the status of jus cogens in positive international law. Unfortunately, there is great uncertainty in this regard. ${ }^{53}$ However, it seems plausible that, in the current state of positive international law, only an intervention involving an unlawful threat or use of force would be a violation of jus cogens, ${ }^{54}$ with other forms or modalities of interference not having hitherto been identified by international practice and case law as a violation of a peremptory norm of international law. Thus, the question of the accepted derogations or exceptions from the right to non-intervention and non-interference as well as the legal implications of its violation bears consideration.

\subsection{Derogations from the right to non-intervention and non-interference}

The issue of derogations from the right to non-intervention and non-interference (meaning the possibility of an interference without unlawful use of force) ${ }^{55}$ is mainly raised in relation to two separate hypotheses: firstly, regarding the intervention upon invitation' hypothesis, notably with the consent or upon request of the territorial state; and secondly, with regard to the so-called 'humanitarian intervention' hypothesis.

With regard to the first, intervention-even a military one-is not in principle unlawful if the territorial host state has given its consent in due form. ${ }^{56}$ If the principle is clear, its implementation can nevertheless be delicate and open to abusive behaviour. For instance, if the requesting government is not in effective control of the territory of the state at the time it makes the request, if it does not have the legal authority and popular support to issue such a request, or if it is engaged in a civil war and requests a third state's intervention in order to suppress the opposition, the actual legality of the intervention upon invitation' principle can be doubtful, especially if the people are allegedly exercising their right to self-determination or to rebel against an oppressive regime. In this regard it must be noted that according to the General Assembly's Declaration on the Inadmissibility of Intervention and Interference in the Internal Affairs of States:

Nothing in this Declaration shall prejudice in any manner the right to self-determination, freedom and independence of peoples under colonial domination, foreign occupation or racist regimes, and the right to seek and receive support in accordance with the purposes and principles of the Charter of the United Nations. ${ }^{57}$

53 cf Anthony D’Amato, 'There is No Norm of Intervention or Non-Intervention in International Law' (2001) 7 Intl Legal Theory 33.

54 On the qualification of the prohibition of illegal use of force as a jus cogens norm, see Nicaragua (n 16) 100-01.

55 The right of self-defence or the authorisation of use of force by the UN Security Council are not exceptions to this peremptory norm, but its mere legal corollaries.

56 See Ian Brownlie, International Law and the Use of Force by States (Clarendon Press 1963) 317; Louise Doswald-Beck, 'The Legal Validity of Military Intervention by Invitation of the Government' (1986) 56 BYBIL 189; Malcolm N Shaw, International Law (7th edn, CUP 2014) 834. See also Nicaragua (n 16) 126: 'intervention (...) [is] allowable at the request of the government of a State'.

57 UNGA Res 36/103 (9 December 1981) UN Doc A/RES/36103, para 4. 
However, intervention in order to restore or establish democracy is by no means permitted under international law. ${ }^{58}$ For the intervention upon invitation to be in conformity with international law, the form and validity conditions of the consent or the request are also open to discussion. The recent example of the Arab League's military intervention in Yemen on 25 March 2015, following a letter sent by embattled President Abed Rabbo Mansour Hadi to the United Nations Security Council, shows exactly how intricate such issues may be in practice. Another question is raised by the possibility of an 'intervention upon invitation' in a state which has no effective government capable of issuing such a request (an example being so-called 'failed' states). Whatever the case may be, when the 'intervention upon invitation' consists of military assistance by a third state, even following an explicit request of the territorial state in order to support the latter in its struggle against non-state actors or individual persons within its territory, any such assistance should be offered with full respect for human rights, fundamental freedoms and humanitarian law. ${ }^{59}$

This last principle underlines the growing importance of human rights protection under contemporary international law. It is this same preoccupation that leads to considerations about an allegedly lawful humanitarian intervention and, more recently, about a responsibility to protect. These notions-which are far from being identicalmay counterbalance the right to non-intervention and non-interference and, depending on the point of view adopted, ${ }^{60}$ can be considered as being in conflict with, or more precisely, as providing lawful exceptions to, this right. They would thus constitute the second case of derogation from the right to non-interference.

As far as humanitarian intervention is concerned, it has been argued that prior illegal government action against a minority group may render unilateral intervention, either by a third state or by an international organisation or a group of states, acceptable and render interference in internal affairs, which would have otherwise been considered unlawful, lawful. International instruments that include clauses with regard to the respect of the non-intervention/non-interference principle sometimes specifically mention that these are only valid for states respectful of the right to self-determination of their people and not responsible for discriminatory policies or violations of the aforementioned right. ${ }^{61}$ The Institut de Droit International Santiago de Compostela Resolution (1989)

58 This was notably one of the grounds given for the invasion of Panama in 1989 by the United States. According to Shaw, 'such a proposition is not acceptable in international law in view of the clear provisions of the UN Charter': Shaw (n 56) 840. See also Oscar Schachter, 'The Legality of Pro-Democratic Invasion' (1984) 78 AJIL 645.

59 IDI, 'Present Problems of the Use of Force in International Law: Sub-Group on Intervention by Invitation' (2011) 74 Annuaire IDI 179, 179-363. For the resolution adopted on military assistance on request, see the same document at 360, art 2.

60 cf Patrick Daillier, 'La responsabilité de protéger, corollaire ou remise en cause de la souveraineté ?' in $L a$ Responsabilité de Protéger: Colloque de Nanterre (Pedone 2007) 41-58; Olivier Corten, 'Droit d'Intervention versus Souveraineté. Actualité et Antécédents d'une Tension Protéiforme’ (2012) 56 Droits: Revue Française de Théorie Juridique 33.

61 Friendly Relations Declaration, art 1, principle 5(7); Definition of Aggression, UNGA Res 3314 (XXIX) (14 December 1974) annex, art 7. 
on The Protection of Human Rights and the Principle of Non-Intervention in Internal Affairs of States states in article 2(2) that:

Without prejudice to the functions and powers which the Charter attributes to the organs of the United Nations in case of violation of the obligations assumed by the members of the Organization, States, acting individually or collectively, are entitled to take diplomatic, economic and other measures towards any other State which has violated the obligation set forth in Article I, provided such measures are permitted under international law and do not involve the use of armed force in violation of the Charter of the United Nations. These measures cannot be considered an unlawful intervention in the internal affairs of that State. ${ }^{62}$

Indeed, it appears generally accepted-even if the debate is not absolutely closed-that humanitarian interference, that is, an intervention, which could be considered as coercive (and thus in principle unlawful), but without any use of force and military action, and a fortiori humanitarian assistance, should be considered lawful under international law.

However, this does not seem to be the case as far as humanitarian intervention coupled with the threat or use of force is concerned. For the latter type of intervention, with regard to intervention involving use of force, there is no overall acceptance of its lawful character; quite the contrary. Indeed, such an intervention would potentially enter into conflict with a jus cogens rule and therefore could only be justified by another general international legal principle allowing the use of force as a corollary of the prohibition of the use of force principle. Thus, only invocation of the right of self-defence or authorisation by the Security Council under Chapter VII of the UN Charter can justify a lawful intervention with use of force. State practice up until the 1990s was relatively clear in this regard. Cases which might have been seen as humanitarian interventions (India-Bangladesh; Tanzania; Uganda; Vietnam-Cambodia; Russia-Georgia) were justified by intervening states on other grounds, claiming notably that their actions were in self-defence, allegedly including the rescue of nationals when the territorial state is unable or unwilling to do so, and that this does not infringe the principles of non-interference and the prohibition of the use of force. The intervening states did not therefore invoke any right, or a fortiori any obligation, of humanitarian intervention. Even after the precedents of Northern Iraq (in 1991) and Kosovo (in 1999), ${ }^{63}$ there remains an aversion to invoking humanitarian intervention as a justification for such conduct. Indeed, NATO's action in Kosovo was not based on a right to humanitarian intervention but on a very extensive (and highly controversial) interpretation of related

62 IDI, 'The Protection of Human Rights and the Principle of Non-Intervention in Internal Affairs of States' (1990) 63 Annuaire IDI 339, 343 (emphasis added).

63 With regard to northern Iraq and Kosovo, it must be noted that the United States has not explicitly accepted any right to a humanitarian intervention. It justified its actions to protect the Kurds in the north of Iraq and the Shia in the south, as well as the NATO action over Kosovo, on grounds other than humanitarian intervention and did not invoke humanitarian intervention when arguing that military action in Syria was necessary even without the approval of the Security Council. Humanitarian intervention was not invoked either for the airstrikes in Iraq in 2014 nor for those in Syria in 2014 and 2015 (see nn 64, 70, 71, 73; see also W Michael Reisman, 'Report of the 10th Commission on "Humanitarian Intervention" and Plenary Discussion of the 25th of August 2015' (2015) 77 Annuaire IDI (forthcoming)). 
Security Council resolutions. Moreover, no cases of humanitarian intervention without international authorisation, invoked and admitted as such beyond any controversy, have been witnessed in the past decade. ${ }^{64}$ International action in Somalia (2005-07 ${ }^{65}$ and 2011), ${ }^{66}$ Libya (2011), ${ }^{67}$ Ivory Coast (2011), ${ }^{68}$ Mali (2013), ${ }^{69}$ Syria $\left(2013^{70}\right.$ and $2014-$

64 Only the United Kingdom mentioned briefly 'humanitarian intervention' in connection with the intervention in Syria, but did not follow through with any action in this regard up until August 2015: see Office of the Prime Minister (United Kingdom), 'Chemical Weapon Use by Syrian Regime: UK Government Legal Position’ (29 August 2013) <https://www.gov.uk/government/publications/chemicalweapon-use-by-syrian-regime-uk-government-legal-position/chemical-weapon-use-by-syrian-regimeuk-government-legal-position-html-version> accessed 2 May 2016. The targeted airstrike in Syria in late August 2015 was nevertheless justified on grounds of self-defence and not of humanitarian intervention: see Patrick Wintour, 'UK Forces Kill British Isis Fighters in Targeted Drone Strike on Syrian City' The Guardian (London, 7 September 2015) <http://www.theguardian.com/uk-news/2015/sep/07/uk-forcesairstrike-killed-isis-briton-reyaad-khan-syria> accessed 2 May 2016.

65 On 14 July 2015, the President of the Security Council issued a statement commending the Intergovernmental Authority on Development (IGAD) and the African Union (AU) for their support for the Transitional Federal Government and the deployment of the IGAD Peace Support Mission in Somalia (IGASOM): see UNSC Presidential Statement 32 (2005) UN Doc S/PRST/2005/32. It is unclear whether IGASOM would have been deemed lawful without this statement. In December 2006, Security Council Resolution 1725 authorised the deployment of IGASOM: see UNSC Res 1725 (6 December 2006) UN Doc S/RES/1725. When, after the failure of the IGASOM initiative, Ethiopia intervened unilaterally, it justified its actions invoking self-defence and the consent of the Transitional Federal Government (TFG). Its intervention was nevertheless condemned by the international community. In February 2007, the Security Council authorised the AU to take 'all necessary measures' in order to protect the TFG: see UNSC Res 1744 (20 February 2007) UN Doc S/RES/1744, para 4.

66 In September and October 2011, Kenya sent troops into Somalia as a reaction to terrorist attacks originating in Somalia. Kenya justified this intervention on the basis of self-defence and, implicitly, consent of the TFG. See, eg, the quotations in Will Ross, 'Kenya's Incursion into Somalia Raises the Stakes' $B B C$ News (17 October 2011) <http://www.bbc.co.uk/news/world-africa-15337464> accessed 2 May 2016. The UN Secretary General did not condemn nor endorse the Kenyan operation, but the Kenyan troops soon integrated AMISOM.

67 See below n 81.

68 UNSC Res 1975 (30 March 2011) UN Doc S/RES/1975, para 6 reiterates the authorisation for the UN Operation in the Ivory Coast to 'use all necessary means (...) to protect civilians under imminent threat of physical violence'.

69 In December 2012, United Nations Security Council Resolution 2085 authorised the International Support Mission in Mali (AFISMA) to take 'all necessary measures' to recover the northern territories of Mali from the armed rebels: see UNSC Res 2085 (20 December 2012) UN Doc S/RES/2085, para 9. Since AFISMA could not be deployed immediately, on 10 January 2013, the Security Council called on member states to provide assistance to the Malian Forces. The following day, France launched military operations against the rebels invoking, in order to justify the intervention, the Security Council authorisation, the host state's consent and self-defence. The Security Council endorsed the French intervention: see UNSC Res 2100 (25 April 2013) UN Doc S/RES/2100.

70 In August 2013, both the United Kingdom and the United States argued that a humanitarian intervention in Syria was necessary, even without authorisation by the Security Council. See White House, 'Statement by the President on Syria' (31 August 2013) <https://www.whitehouse.gov/the-press-office/2013/08/31/statementpresident-syria> accessed 2 May 2016; Office of the Prime Minister (United Kingdom) (n 64). Several other states expressed support for US military action. However, the Joint Special Representative of the United Nations and the League of Arab States for Syria stated that a Security Council authorisation was necessary: see, eg, Secretary-General of the United Nations, 'Remarks Made by Lakhdar Brahimi, the Joint Special Representative for Syria, Following his Meeting with Russian Foreign Minister Sergey Lavrov’ (6 September 
15), ${ }^{71}$ Central African Republic (2013) $)^{72}$ and Iraq (2014) ${ }^{73}$ support this affirmation. The most recent example to date, namely the United Kingdom's targeted airstrikes in Syria in August 2015, justified on grounds of self-defence and not of humanitarian intervention, also supports this affirmation. The Institut de Droit International considered in 2007, 2013 and once again in August 2015, after thorough examination of state practice (including the examples cited above), ${ }^{74}$ that there were no grounds to adopt a resolution on the lawfulness of humanitarian intervention not authorised by the United Nations and involving military actions.

In sum, a unilateral (individual or collective) right of humanitarian intervention with use of force invoked independently of the other grounds justifying a lawful use of force (notably on the basis of consent of the host state, authorisation by the Security Council or self-defence) has not achieved the status of positive international law. That being said, self-defence and, mostly in practice, authorisation by the Security Council can justify the use of force and, consequently, a so-called 'humanitarian intervention' involving the use of force. In this regard, recent Security Council practice shows a tendency to 'humanise ${ }^{75}$ the 'threat to international peace and security' as conceived under Chapter VII of the UN Charter, assimilating the distress of civil populations and the flagrant and systematic violation of human rights (in other words, any overwhelming humanitarian crisis) to a threat to international peace and security. ${ }^{76}$

2013) <http://www.un.org/sg/offthecuff/index.asp?nid=2976> accessed 2 May 2016. Although Russia and China have vetoed any resolution authorising military intervention, no unilateral action has taken place.

71 In September 2014, the United States launched airstrikes on Islamic State of Iraq and the Levant (ISIL) targets in Syria. The legal justification invoked by the United States in order to justify the attacks was not humanitarian intervention but individual and collective self-defence under art 51 of the UN Charter, see White House (n 70).

72 In July 2013, the AU authorised the deployment of the African-led International Support Mission in the Central African Republic (MISCA) and four months later it urged the Security Council to adopt a resolution. The Security Council adopted Resolution 2127 on 5 December 2013, authorising MISCA and France to take 'all necessary measures' to protect civilians and stabilise the country: see UNSC Res 2127 (5 December 2013) UN Doc S/RES/2127, para 28.

73 In August 2014, after thousands of Yazidis had fled to Mount Sinjar, the Security Council issued a press statement calling on the international community to support the Government and people of Iraq attacked by ISIL: UNSC, 'Security Council Press Statement on Iraq' (7 August 2014) UN Doc SC/11515-IK/683. The same day the USA government authorised airstrikes against the ISIL. The legal justification invoked by the United States was self-defence on the one hand ('targeted airstrikes to protect our American personnel') and Iraqi consent on the other hand; humanitarian intervention was not invoked as such, since the operation 'to help Iraqi civilians stranded on the mountains' was conducted with the permission and 'at the request of the Iraqi government': see White House, 'Statement by the President' (7 August 2014) <https:// www.whitehouse.gov/the-press-office/2014/08/07/statement-president> accessed 2 May 2016.

74 Reisman (n 63).

75 cf Linos-Alexandre Sicilianos, 'L'Influence des Droits de l'Homme sur la Structure du Droit International: Première Partie: La Hiérarchisation de l'Ordre Juridique International' (2012) 116 RGDIP 5; LinosAlexandre Sicilianos, 'L'Influence des Droits de l'Homme sur la Structure du Droit International: Deuxième Partie: Les Conséquences Structurelles de la Hiérarchisation’ (2012) 116 RGDIP 241.

76 cf Mathias Forteau, 'Le Conseil de Sécurité des Nations Unies est-il Soustrait à l'Emprise du Principe de Non Intervention?' (2013) 57 Droits: Revue Francaise de Théorie, de Philosophie et de Culture Juridique 119. 
The 2005 World Summit Outcome ${ }^{77}$ and the advent of the responsibility to protect principle reinforces both the above mentioned statements: namely the absence of any unilateral right to humanitarian intervention involving a use of force, and the Security Council's 'humanisation' of the notion of international peace and security threats. Indeed, moving away from a doubtful right of humanitarian intervention and towards a concept more respectful of state sovereignty and of the right to non-interference, the Heads of State and Government noted in the 2005 World Summit Outcome that '[e]ach individual State has the responsibility to protect its populations from genocide, war crimes, ethnic cleansing and crimes against humanity. ${ }^{\text {' }}$ They went on to say that ' $[\mathrm{t}]$ he international community, through the United Nations' also has the responsibility to use appropriate means and that:

In this context, we are prepared to take collective action, in a timely and decisive manner, through the Security Council, in accordance with the Charter, including Chapter VII, on a caseby case basis and in cooperation with relevant regional organizations as appropriate, should peaceful means be inadequate and national authorities are manifestly failing to protect their populations from genocide, war crimes, ethnic cleansing and crimes against humanity. ${ }^{79}$

Thus, the responsibility to protect concept as outlined in the 2005 World Summit Outcome establishes a subsidiary right for the international community to intervene in order to protect civilian populations, when the territorial state is failing to do so (meaning that is unable or unwilling), even without the latter's consent. It also confirms that enforcement action to protect human rights is within the Security Council's powers under Chapter VII. It remains to be seen if such a principle will become part of positive international law as an autonomous right, the 2005 World Summit Outcome having no binding legal authority per se. This is far from being the case. Article 4(h) of the Constitutive Act of the African Union consecrates a right of intervention of the African Union based on the concept of responsibility to protect. Still, it must be noted that recent practice shows that the African Union in most cases seeks Security Council authorisation before itself authorising, or in any case before deploying, an intervention. ${ }^{80}$ Furthermore, despite the silence of the UN Charter on the matter, the Security Council has already used the concept of the responsibility to protect to authorise use of force to avert or put an end to several humanitarian crises. Even though it failed in 2007 to adopt a resolution dealing with Myanmar, because it was vetoed by two permanent members of the Council, namely China and Russia, since 2009 several General Assembly and Security Council Resolutions have expressly or implicitly invoked the concept of the responsibility to protect. $^{81}$ This was notably the case in Resolution 1973 of 17 March 2011 dealing with

77 UNGA, '2005 World Summit Outcome' (20 September 2005) UN Doc A/60/L.1.

78 ibid 138 .

79 ibid 139 (emphasis added).

80 See above nn $65,72$.

81 The first to do so was UNGA Res 63/308 (14 September 2009) A/RES/63/308. For Security Council resolutions (either authorising use of force or recognising a threat to international peace and security), see 
the Libyan crisis, in which the Security Council referred to the responsibility to protect concept in order to allow member states to take 'all necessary measures. ${ }^{82}$ However, the consent of the local authorities minimises the authority of such a precedent. Moreover, the NATO operations were heavily criticised by the international community for having overstepped the United Nations mandate and the scope of Resolution 1973.

In any case, as long as the subsidiary right deriving from the responsibility to protect does not offer grounds for a unilateral action but only invites the international community as a whole to intervene-probably solely upon authorisation of the Security Council whenever a potential use of force is at stake-one can argue that such a principle does not bring any substantial modification to international law. ${ }^{83}$ Still, it is often contended that the responsibility to protect concept offers additional grounds for a right of the General Assembly to authorise an intervention in case of humanitarian crisis whenever the territorial state is unwilling or unable to put an end to it and the Security Council is paralysed because of the permanent members' vetoes, ${ }^{84}$ or that the Security Council authorisation/validation might be retroactive or informal. Nevertheless, such possibilities are not generally accepted and it remains highly doubtful if they are allowed by the UN Charter and by positive international law.

Despite the numerous aforementioned grey areas, it seems quite clear that whenever derogations from the right to non-intervention and non-interference are admitted by positive international law, the phenomenon in question is that of an exception or a corollary to the above said right or, in other words, an application of the lex specialis derogat generalis principle. Thus, the 'intervening' or 'interfering' state is not faced with two contradictory international obligations equally enforceable upon it, and does not find itself in a legal impasse leading it to violate one of the two and therefore to necessarily engage its international responsibility. In fact, a lawful interference does not violate the prohibition on non-intervention/non-interference and, if the particular conditions already examined are met, even the use of force can be deemed lawful. In any case, it must be stated that even if a doctrine of a right—or even a duty-of humanitarian intervention was admitted in international law, it should not be considered as such contrary to state sovereignty and corollary fundamental rights. ${ }^{85}$ Indeed, all

UNSC Res 1706 (31 August 2006) UN Doc S/RES/1706 (Darfur); UNSC Res 1894 (11 November 2009) UN Doc S/RES/1894 (establishing the normative context of the responsibility to protect); UNSC Res 1970 (26 February 2011) UN Doc S/RES/1970 (Libya); UNSC Res 1973 (17 March 2011) UN Doc S/RES/1973 (Libya); UNSC Res 1975 (Ivory Coast); UNSC Res 2127 (Central African Republic). See Sandra Szurek, 'La Responsabilité de Protéger: Du Prospectif au Prescriptif ... et Retour. La Situation de la Libye devant le Conseil de Sécurité' (2012) 56 Droits: Revue Française de Théorie Juridique 58.

82 UNSC Res 1973, para 4: 'Authorizes Member States that have notified the Secretary-General, acting nationally or through regional organizations or arrangements, and acting in cooperation with the Secretary-General, to take all necessary measures, notwithstanding paragraph 9 of resolution 1970 (2011), to protect civilians and civilian populated areas under threat of attack in the Libyan Arab Jamahiriya, including Benghazi' (emphasis added). See also UNSC Res 1970.

83 Olivier Corten, Le droit contre la guerre (Pedone 2008) 766-74.

84 See IDI, 'Authorization of the Use of Force by the United Nations' (2011) 74 Annuaire IDI 365, 365-484.

85 Corten, 'Droit d'Intervention versus Souveraineté' (n 60) 37-38. 
the hypotheses of such an intervention are founded on the absence of the territorial state's exercise of sovereignty and on the necessity to protect the human rights of its population. That being said, the right to non-intervention and non-interference can beand is in fact often-violated when the invocation of a lawful derogation to it (such as consent, self-defence or authorisation by the Security Council), in order to justify an intervention, is proving to be abusive, fallacious or overstepping the mandate authorised by the Security Council. The examples of states, groups of states or even international organisations having violated other states' right to non-intervention and non-interference are numerous. The possible legal consequences of such violations shall thus be the last point examined by this article.

4.2 Legal implications of the violation of the right to non-intervention and noninterference

The consequences of a violation of the right to non-intervention and non-interference will of course be those determined by general international law. Therefore, the legal implications of such a violation will be examined here briefly, since it suffices to refer to the general international law of state responsibility and the validity of international legal acts. However, it must be emphasised that the consequences of the violation of the right to non-intervention and non-interference depend first of all on whether the violated rule has gained the status of jus cogens. Indeed, the implications of the violation of a peremptory international norm are partially different from those of the violation of other norms. Hence, the hypothesis of an unlawful interference or intervention with illegal threat or use of force is to be distinguished from the hypothesis of an unlawful interference or intervention without use of force.

As far as the latter is concerned-a coercive but non-military illegal interference in the internal affairs of a state-there seems to be no violation of a jus cogens norm. Thus, the legal implications of such an interference will be nothing more than the common consequences of any violation of conventional or customary international law, meaning the engagement of the interfering state's (or international organisation's) responsibility, its secondary obligation for reparation of the prejudice caused to the damaged state (in the sense of article 31 of the Articles on Responsibility of States for Internationally Wrongful Acts, drafted by the International Law Commission (ILC)), ${ }^{86}$ and the eventual possibility of the latter to adopt countermeasures. ${ }^{87}$

Turning now to the first-and relatively more complex-hypothesis, if the intervention or interference constitutes simultaneously a violation of the prohibition on the threat or use of illegal force and thus violates jus cogens, its consequences will be those of any violation of a peremptory norm of international law. Therefore, the

86 ILC, Articles on Responsibility of States for Internationally Wrongful Acts, adopted through UNGA Res 56/83 (12 December 2001) UN Doc A/RES/56/83 (Articles on State Responsibility).

87 ibid arts $49-51$. 
legal implications of such an unlawful interference or intervention would be twofold, in terms of validity of certain legal acts on the one hand and in terms of international responsibility on the other.

In fact, according to the law of treaties, an international treaty is null and void if it is procured in violation of the prohibition on the threat or use of force or if it conflicts with a peremptory norm of international law. ${ }^{88}$ Thus, an illegal coercion against a signatory state, meaning any threat or use of force against it, ${ }^{89}$ suffices to invalidate the treaty in question. Consequently, whenever the violation of the right to non-intervention and noninterference involves the threat or use of force, any treaty signed or ratified by the 'victim' state would be null and void ex tunc. Mutatis mutandis, unilateral acts that constitute a violation of the right to non-interference and-at the same time-of the prohibition of threat or use of force should be considered null and void and thus deprived of any legal effect ex tunc. This is obviously the case as far as annexation is concerned (for instance, the Security Council has declared that the annexation of Jerusalem by Israel, and of Kuwait by Iraq, were null and void). However, even other unilateral acts of states, not materially implicating the use of force per se but constituting an illegal threat of use of force as well as a wrongful interference in the internal affairs of a state (a premature recognition following secession, for instance, doubled by an international promise to use force against the state opposed to the secession) can be considered as null and void because of their contrariety to a peremptory norm of international law.

Moreover, any situation resulting from an unlawful intervention or interference with the threat or use of force would be covered by the obligation of non-recognition stipulated in article 41 of the ILC's Articles on Responsibility of States for Internationally Wrongful Acts. ${ }^{90}$ Finally, in terms of international responsibility, an interference that violates the

88 Vienna Convention on the Law of the Treaties (adopted 23 May 1969, entered into force 27 January 1980) 1155 UNTS 331, arts 52-53 (VCLT).

89 It is doubtful whether art 52 of the VCLT covers solely the illegal threat or use of force or other forms of coercion as well. It seems, in the actual state of positive international law, that only a use of force or coercion implicates the nullity of the treaty. In this regard, it must be noted that the 'Declaration on the Prohibition of Military, Political or Economic Coercion in the Conclusion of Treaties' concerning the adoption of international treaties is annexed to the Final Act of the VCLT but does not have binding legal authority. Article 52 appears therefore to only cover the hypothesis of illegal threat or use of force and the international practice supports this affirmation. On the interpretation of art 52, see Olivier Corten, 'Article 52' in Olivier Corten and Pierre Klein (eds), Les Conventions de Vienne sur le Droit des Traités: Commentaire Article par Article, vol 2 (Bruylant 2006) 1667-900, notably 1873-85; Sir Humphrey Waldock, 'Fifth Report on the Law of Treaties' ILC YB 1966/II(1) 21.

90 ILC, Articles on State Responsibility. On this question, see Joe Verhoeven, La Reconnaissance Internationale dans la Pratique Contemporaine: Les Relations Publiques Internationales (Pedone 1975) 227; Verhoeven, 'La Reconnaissance Internationale: Déclin ou Renouveau?' (n 50) 39; Stefan Talmon, La Non-reconnaissance Collective des États Illégaux (Pedone 2007) 113; Stefan Talmon, "The Duty Not to "Recognize as Lawful" a Situation Created by the Illegal Use of Force or other Serious Breaches of a Jus Cogens Obligation: An Obligation Without Real Substance?' in Christian Tomuschat and Jean-Marc Thouvenin (eds), The Fundamental Rules of the International Legal Order: Jus Cogens and Obligations Erga Omnes (Martinus Nijhoff Publishers 2006); Théodore Christakis, 'L'Obligation de Non-Reconnaissance des Situations Créées par le Recours Illicite à la Force ou d'Autres Actes Enfreignant des Règles Fondamentales' in Christian 
prohibition of threat or use of force and thus a peremptory norm of international law will entail all legal consequences of such a violation codified notably in article 40 of the same ILC Articles. In addition to the aforementioned obligation of non-recognition, these legal implications include the possibility for a 'State other than an injured State' to invoke the interfering state's international responsibility in the conditions specified by article 48 of the ILC Articles.

\section{Conclusion}

In conclusion, even though, according to a common narrative, the right to nonintervention and non-interference is often portrayed as a fundamental right of states, it appears, as this article has argued, that it is more so in name than in substance. As was argued above, both the autonomous existence of this right as an independent rule (that is, a liberty) and its fundamental character can be seriously questioned. More worthy of examination are its scope and legal implications. In this respect, it has been shown that the most important question is probably whether this right has achieved the status of a jus cogens norm. The international law and practice examined in this article show that this is not the case. Only the core principle of the right entailing the prohibition of an intervention or an interference with the threat or use of illegal force is of a jus cogens order. It remains, as was argued here, that this superior normative authority does not warrant any alleged fundamental character of the right to non-intervention and noninterference per se. 